\title{
Diversity and Taxonomy of Basidiomycetous Fungi at the Northeastern Side of Quezon Protected Landscape, Southern Luzon, Philippines
}

Felimon Pacle Brazas $\mathrm{Jr}^{1,5}$, Liwayway Perlado Taglinao, ${ }^{2,5}$, Arianne Grace Mapacpac Revilla ${ }^{3,5}$, Raymundo Fajardo Javier ${ }^{4,5}$ and Edwin Roces Tadiosa ${ }^{4,5}$

1. Department of Liberal Arts, Education and Sciences, San Pedro College of Business Administration, San Pedro City, 4023, Laguna, Philippines

2. Department of Biological Sciences, College of Arts and Sciences, Cavite State University, Indang 4122, Cavite, Philippines

3. Senior High School Department, Dasmariñas East Integrated High School, San Simon, Dasmariñas City, 4115, Cavite, Philippines

4. Science Department, College of Science, Bulacan State University, Guinhawa St., Malolos City, 3000, Bulacan, Philippines

5.College of Science and Computer Studies-Graduate Studies, De La Salle University, Dasmariñas City, 4115, Cavite, Philippines

\begin{abstract}
The present study was conducted primarily, to determine the diversity of basidiomycetous fungi and their taxonomy, in the northeastern side of Quezon Protected Landscape, bordering the municipalities of Pagbilao, Padre Burgos and Atimonan in Quezon province, Southern Philippines. Ten quadrats measuring $10 \mathrm{~m} \times 15 \mathrm{~m}$ with an interval of $50 \mathrm{~m}$ were established from a transect line set up from the baseline to the peak of the landscape. Species of basidiomycetous fungi were pre-identified in the field. Substratum, form, texture, size, color and other noteworthy characteristics were recorded during the time of collection. Confirmation of identities was done using published textbooks, literature and consultation with mycology expert. A total of 863 individuals of basidiomycetous fungi were collected and identified belonging to 19 different families, 31 genera and 53 species. Polyporaceae family has the highest number of species representing $30 \%$ of the total number of individuals documented. Most of the species belong to Hexagonia and Polyporus genera. The current research revealed that most of the substrates used by these fungal organisms are woody substrate, specifically rotten woods. The results of Shannon-Wiener diversity index showed that the area has a high basidiomycetous fungal diversity. There was also a high species richness of these fungal organisms, but there was a low dominance and the species were not evenly distributed in the area. As this area is open for hikers, it is recommended that a continuous monitoring of the macrofungi community be done for sustainability and conservation.
\end{abstract}

Key words: Atimonan, basidiomycetous, diversity, Hexagonia, macrofungi, northeastern side, Quezon Protected Landscape, Polyporaceae.

\section{Introduction}

Fungi are eukaryotic organisms which are historically included in the plant kingdom. However, because they lack chlorophyll and are distinguished by unique structural and physiological features, they have been separated from plants and are clearly distinguished from all other living organisms,

Corresponding author: Felimon Pacle Brazas Jr, Ph.D. student, research field: biology. including animals, by their principal modes of vegetative growth and nutrient intake, such digestion of organic matter externally before absorbing it into their mycelia [1]. Fungi are able to secrete enzymes that are capable of breaking down virtually all classes of plant compounds. Thus, fungi can decompose substrates such as fresh plant litter and some structural materials (e.g., lignin, chitin and keratin) that are initially almost inaccessible to other decomposers [2]. Moreover, fungi account for a large fraction of the soil 
microbial biomass, as they contribute to about $60 \%-90 \%$ of the microbial biomass in forest soils and to $50 \%$ in grassland soils. Fungi have extensive hyphae networks, which make it possible to acquire carbon (e.g., from forest litter) and nutrients (e.g., from mineral soil) from different locations. Mycorrhizae are symbiotic associations between fungi and plant roots. Based on conservative estimates, approximately $95 \%$ of all vascular plant species have the potential to form this mutualistic association with mycorrhizal fungi [3].

Due to these characteristics, fungi are very diverse in nature. According to Nacua et al. [4], there are approximately 1.5 million fungal species found in the whole wide universe, of which only 70,000 have been described and identified. This accounts for only a small percent of these organisms that need to be discovered, described and recorded. It is quite important to study their diversity and taxonomy in different parts of the world before these organisms would vanish in the earth. Loss of diversity is a problem at least as large for fungi as for plants and animals, but fungi are not usually a high profile group. Red Lists are being constructed for fungi using International Union for the Conservation of Nature categories, though use of criteria for plants and animals is not always straight forward [5].

Four large phyla comprise these organisms such as Basidiomycota, Ascomycota, Deuteromycota and Zygomycota. Of these phyla, macrofungi which are the focus of the present study, belong to either Basidiomycetes and Ascomycetes that were characterized by easily observable structures of the produced spores that form either above or underground [6].

Philippines is one of the mega diverse countries in the world, but only few researches on fungal diversity and taxonomy have been conducted in the area. Some of the studies were conducted in Mt. Palay-Palay Mataas na Gulod National Park [7, 8], Taal Volcano Protected Landscape in Tagaytay [9], Mt. Apo in
Mindanao [10], Mt. Malinao, Albay [11], Mt. Makiling Forest Reserve, Laguna [4, 12-14], Puncan, Carranglan, Nueva Ecija [15], Sierra Madre Mountain Range, Cagayan province [16] and Bazal-Baubo Watershed, Aurora province [17]. The present study was conducted in the northeastern part of Quezon Protected Landscape (Quezon National Park) of the Municipalities of Pagbilao, Padre Burgos and Atimonan in Quezon province, Philippines, and primarily aimed to determine the diversity of macrofungi, specifically the basidiomycetous fungi and their taxonomy in this area. The park is situated north of the narrowest section of Luzon in Quezon province, located about 164 km (102 miles) Southeast of Metro Manila with coordinates 13⒌'22" N, $121^{\circ} 48^{\prime} 59^{\prime \prime} \mathrm{E}$.

Knowing the different species of Basidiomycetes and its classification will help one to understand their functions and role in the ecosystems and categorize species to organize the diversity of life in the environment. This study presents the different species of basidiomycetous fungi with their classifications which is very important in this present time since fungi are affected by habitat loss, pollution, climate change and other environmental factors, so the local government can implement protection and conservation program for these fungi.

\section{Materials and Methods}

\subsection{Study Site}

Quezon Protected Landscape (Fig. 1) is a tropical rainforest under the protection of the Department of Environment and Natural Resources-Protected Areas and Wildlife Bureau, University of the Philippines Center for Integrative and Development Studies and Conservation International Philippines. It is geographically located $13^{\circ} 59^{\prime} 22.308^{\prime \prime} \mathrm{N}$ latitude and $121^{\circ} 48^{\prime} 59.0508^{\prime \prime} \mathrm{E}$ longitude and is 366 meters above the sea level (masl). The protected rainforest is 983.0765 ha, a tropical rainforest that spans five barangays of Quezon namely: Silangang Malicboy in 


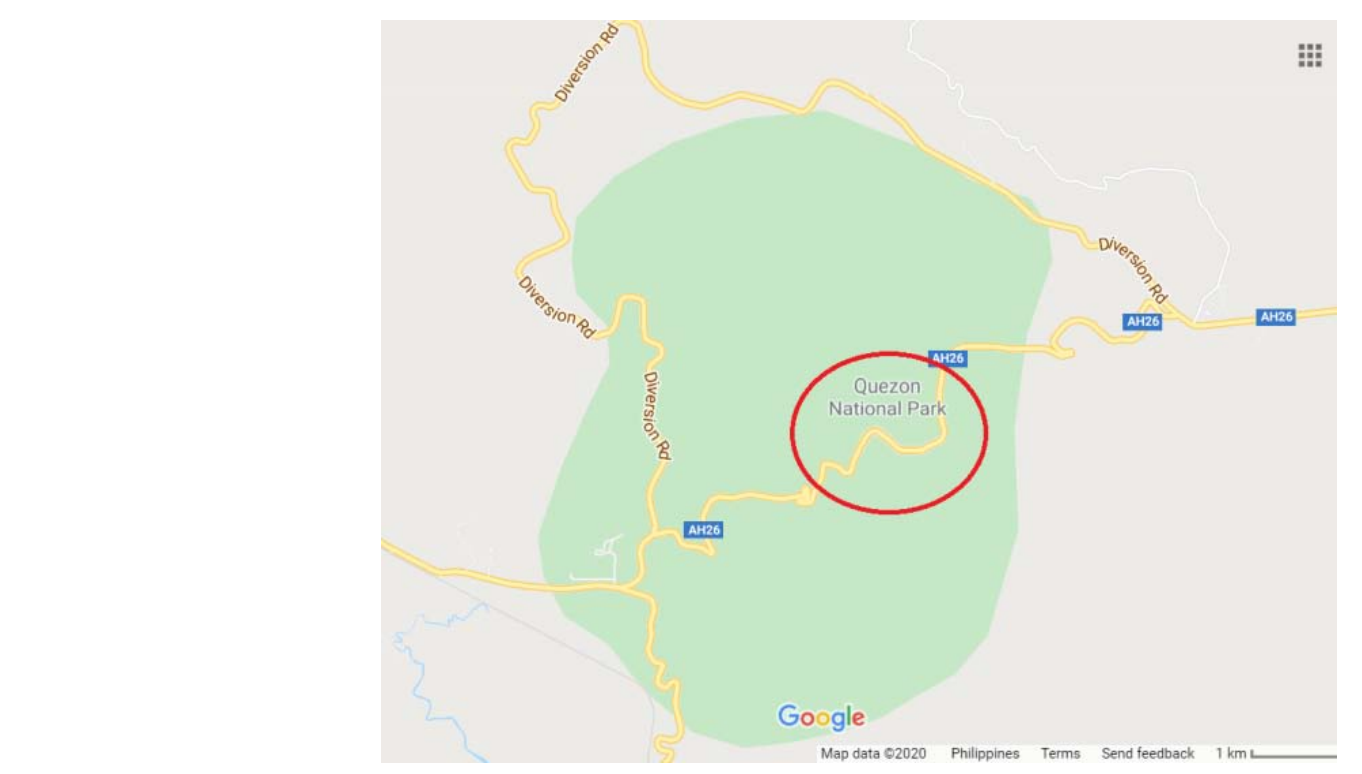

Fig. 1 Map showing the location of the study site.

Pagbilao, Sipa and Hanguiwin in Padre Burgos and Sta. Catalina and Malinao Ilaya in Atimonan.

\subsection{Collection and Documentation of Fungi}

Transect line and quadrat methods were used in the field samplings [18]. Ten quadrats were established in the identified transect line of study site that were set up from the baseline to the peak of northeastern part of Quezon Protected Landscape. Each quadrat has a size of $10 \mathrm{~m} \times 15 \mathrm{~m}$ with an interval of $50 \mathrm{~m}$ in between.

Species found in each quadrat were pre-identified in the field. All basidiomycetous fungi were photographed in their natural habitat using a Canon DS126231 (DC 8.1 V) camera. Coordinates of each fungus were recorded through the use of global positioning system (GPS) [7]. Substratum, form, texture, size, color and other noteworthy characteristics were recorded during the time of collection. Samples of each species were collected, tagged, placed in a clean plastic and brought to the De La Salle University-Dasmariñas laboratory for proper identification and classification. Fragile and fleshy specimens were preserved in denatured alcohol and kept in vials and woody specimens were immediately air dried.

\subsection{Identification and Classification of Fungi}

Collected specimens were thoroughly analyzed using the macroscopic and microscopic attributes of the fruiting bodies [19]. Proper identification and classification was made by comparing the collected specimens with photos presented in the handbook on mushroom [20], National Audubon Society Field Guide to North American Mushrooms [21] and consultation with expert in the field of mycology.

\subsection{Measurement of Basidiomycetous Fungal Diversity}

Basidiomycetous fungal diversity was computed using Shannon-Wiener diversity index ( $\left.\mathrm{H}^{\prime}\right)$ [14]. This is to measure the species abundance and richness in the area. Only those species of fungi found within the transect were included for the computation of the diversity.

\section{Results and Discussion}

\subsection{Taxonomy and Substrate of Collected Basidiomycetous Fungi}

A total of 863 individuals of basidiomycetous fungi were collected from the area after field sampling using a transect with 10 quadrats. These were identified 
belonging to 19 different families, 31 genera and 53 species (Table 1). Polyporaceae family has the highest number of species representing $30 \%$ of the total number of individuals documented, most of which belong to the genera Hexagonia and Polyporus. The abundance of Hexagonia and Polyporus fungi could be attributed to the amount and diversity of coarse woody debris which they use as substrate [22]. The second highest number of individuals belongs to the Mycenaceae family which represents $26 \%$ of the total number of individuals collected, of which most of the genera belong to Mycena (Table 1). Fig. 2 represents samples of basidiomycetous fungi collected from the Northeastern Side of Quezon.

Fungi depend on a wide variety of substrates including soil, rotten wood, leaf litter, trees, shrubs, dead grass, etc., but the current study shows that basidiomycetous fungi mostly use woody substrates most especially rotten woods. These rotten woods have a crucial role in a forest biodiversity [23]. Some of the fungi degrade the cellulose in woods making cavities that would eventually decompose the woods [24]. Polypores and other white-brown-rot fungi are considered as the most important wood decomposer [25].

\subsection{Diversity of Basidiomycetous Fungi}

In Table 2, fifty-three (53) species of basidiomycetous fungi were identified using books and guides of fungi identification. Shannon-Wiener index was used to determine the diversity of the basidiomycetous fungi [14]. The computed value was 4.15 which is such a high value indicating that the northeastern part of the Quezon Protected Landscape has a high basidiomycetous fungal diversity. The genera with the highest number of individuals were obtained by the species Hebeloma mesophaeum (107) representing $12 \%$ of the total number of collected individuals showing that this is the most abundant or the most dominant species in the area. These dominant fungal species are probably the densest and the important decomposers [26] in this area. This was followed by the Polyporus sp. which has total number of 89 representing $10.3 \%$ of the total number of fungal individuals. The study also revealed that there was a high species richness of these fungal organisms.

Shannon-Wiener index is given by the following formula:

$$
H^{\prime}=-\sum[(p i) \times \ln (p i)]
$$

where $N=$ number of individuals; $p i=$ proportion of total sample represented by species $i$; $S=$ number of species $=$ species richness; $H_{\max }=\ln (S)=$ maximum diversity possible; $E=$ evenness $=H / H_{\max }$.

Therefore:

$$
\begin{aligned}
& H^{\prime}=4.14883944 \text { or } 4.15 ; \\
& H_{\max }=\ln (S)=\ln 53=3.970292 \text { or } 3.97 ; \\
& E=4.15 / 3.97=1.04534 \text { or } 1.05 ;
\end{aligned}
$$

Shannon diversity $(H)=4.14883944$;

Evenness $=1.05$

For species richness (using Margalef's index (M)) [27]:

$$
d=(S-1) / \ln (N)
$$

where $d=$ Margalef's diversity index; $S=$ total number of species; $N=$ number of individuals.

Therefore:

$$
d=(53-1) / \ln 863=7.691835838 \text {. }
$$

\subsection{Effect of Relative Humidity in the Growth of Fungi}

In the present study, relative humidity ranges from $78 \%$ to $100 \%$ and there was a number of basiodiomycetous fungal species found in each quadrat as presented in Table 3. Sixty-four (64) species were documented in the entire transect line, but since two or more quadrats share the same species, a total of 53 species were identified. This shows that a high relative humidity positively influenced the growth of a variety of fungal species. Fungi can grow quickly in moist or humid conditions because these are two of the fundamental requirements for fungal growth. Similarly, increased concentration of spores of basidiomycetous fungi like Ganoderma spores is associated with the high level of humidity such as $70 \%$ [28]. Aside from relative humidity, there are other factors that would contribute to the growth of 
fungi in an environment such as wind and increased, the spores are also distributed at a fast rate. temperature. Wind speed affects the distribution of basidiomycetous spores, such that if the wind speed is In addition, an increase in temperature enhances the growth of fungal populations [29].

Table 1 Taxonomy, substrate and the number of individuals per family of the collected basidiomycetous fungi.

\begin{tabular}{|c|c|c|}
\hline Taxa & Substrate & Number of individuals \\
\hline \multicolumn{3}{|l|}{ Agaricaceae } \\
\hline Coprinus niveus (Pers. Fr.) & Soil & 3 \\
\hline C. stercoreus (Fr., Epicrisis) & Rotten wood & 1 \\
\hline Leucocoprinus fragilissimus (Berk. \& M.A. Curtis) & Leaf litter, decayed plant matter & 2 \\
\hline Subtotal & & 6 \\
\hline \multicolumn{3}{|l|}{ Auriculariaceae } \\
\hline Auricularia auricula (Bull.) J. Schrot & Trees and shrubs & 49 \\
\hline A. polytricha (Mont.) Sacc. & Rotten wood & 29 \\
\hline Subtotal & & 78 \\
\hline \multicolumn{3}{|l|}{ Bolbitiaceae } \\
\hline Conocybe tenera (Schaeff.) & Dead grass, decayed woods, and dung & 7 \\
\hline Panaeolus papilionaceus (Bull. ex Fries) Quelet & Wood and pastures & 11 \\
\hline Subtotal & & 18 \\
\hline \multicolumn{3}{|l|}{ Cortinariaceae } \\
\hline Cortinarius sp. & Soil & 1 \\
\hline Subtotal & & 1 \\
\hline \multicolumn{3}{|l|}{ Crepidotaceae } \\
\hline Crepidotus variabilis (Pers.) P. Kumm. & Dead twigs of broad-leaved trees & 42 \\
\hline Subtotal & & 42 \\
\hline \multicolumn{3}{|l|}{ Entolomataceae } \\
\hline Entoloma cetratum (F.) M. M. Moser & $\begin{array}{l}\text { Grasses and woods, can form mycorrhizal } \\
\text { relationships }\end{array}$ & 8 \\
\hline Subtotal & & 8 \\
\hline \multicolumn{3}{|l|}{ Fomitopsidaceae } \\
\hline Daedalea ambigua (Berk) & Wood & 6 \\
\hline Subtotal & & 6 \\
\hline \multicolumn{3}{|l|}{ Ganodermataceae } \\
\hline Ganoderma applanatum (Pers.) Pat. & Wood & 3 \\
\hline G. lucidum (Curtis) P. Karst. & Wood & 1 \\
\hline Subtotal & & 4 \\
\hline \multicolumn{3}{|l|}{ Hygrophoraceae } \\
\hline Hygrocybe nitida (Berk. \& M.A. Curtis) & Rotten wood & 4 \\
\hline Subtotal & & 4 \\
\hline \multicolumn{3}{|l|}{ Hymenochaetaceae } \\
\hline Phellinus igniarius (L.) Quel. & Trunk of trees & 16 \\
\hline P. punctatus (Fr.) Pilat. & Trunk and branches of trees & 5 \\
\hline Subtotal & & 21 \\
\hline \multicolumn{3}{|l|}{ Hymenogastraceae } \\
\hline Hebeloma mesophaeum (Pers.) Quel. & Soil & 107 \\
\hline Subtotal & & 107 \\
\hline \multicolumn{3}{|l|}{ Marasmiaceae } \\
\hline Crinipellis scabella (Alb. \& Schwein.) & Leaf litter, soil & 2 \\
\hline Marasmius haematocephalus (Mont.) Fr. & Rotten wood and soil & 1 \\
\hline M. scorodonius (Fr.) A. W. Wilson and Desjardin & Soil and leaf litter & 3 \\
\hline
\end{tabular}


(Table 1 to be continued)

\begin{tabular}{|c|c|c|}
\hline Таха & Substrate & Number of individuals \\
\hline Marasmius sp. & Soil and leaf litter & 17 \\
\hline Subtotal & & 23 \\
\hline \multicolumn{3}{|l|}{ Mycenaceae } \\
\hline Favolaschia pustulosa (Jungh.) Kuntze & Wood & 1 \\
\hline Mycena acicula (Schaeff.) P. Kumm. & Wood & 8 \\
\hline M. alcalina (Pers.) Gillet & Branches of tree and rotten log or wood & 60 \\
\hline M. cinerella (P. Karst.) & Soil, leaf litter and similar detritus & 20 \\
\hline M. clavularis (Batsch) Sacc. & Bark of trees & 52 \\
\hline M. fibula (Fr.) Kuhner & Bark of trees and leaf litter & 9 \\
\hline M. galericulata (Scop.) Gray & Rotten wood and soil & 3 \\
\hline M. galopus (Pers.) P. Kumm. & Leaf litter & 1 \\
\hline M. pura (Pers.) P. Kumm. & Wood and soil & 3 \\
\hline M. vulgaris (Pers.) P. Kumm. & Leaf litter, soil and wood & 69 \\
\hline Subtotal & & 226 \\
\hline \multicolumn{3}{|l|}{ Polyporaceae } \\
\hline Earliella scabrosa (Pers.) Gilb. \& Ryvarden & Trunk of trees, rotten wood and soil & 20 \\
\hline Favolus alveolaris (DC.) Quel & $\begin{array}{l}\text { Branches and twigs of hardwoods and } \\
\text { dead hardwoods }\end{array}$ & 1 \\
\hline Hexagonia glaber (P. Beauv.) Ryvarden & Rotten wood & 7 \\
\hline H. nitida Durieu \& Mont. & Rotten wood & 12 \\
\hline H. tenuis (Hook.) Fr. & Branches and twigs of trees & 4 \\
\hline Lentinus velutinus Fr. & Soil and leaf litter & 21 \\
\hline Microporus affinis (Blume \& T. Nees) Kuntze & Wood, rotting wood and trunk of trees & 2 \\
\hline M. xanthopus (Fr.) Kuntze & Woody substrate & 24 \\
\hline Polyporus badius (Pers.) Schwein. & Wood substrate esp. decaying woods & 1 \\
\hline Polyporus sp. 1 & Woody substrate & 53 \\
\hline Polyporus sp. 2 & Woody substrate & 89 \\
\hline Poria sp. & Wood & 20 \\
\hline Trametes ochracea (Pers.) Gilb \& Ryvarden & Decaying logs and woods & 1 \\
\hline T. versicolor (L.) Lloyd & Decaying woods & 8 \\
\hline Subtotal & & 263 \\
\hline \multicolumn{3}{|l|}{ Psathyrellaceae } \\
\hline Coprinellus micaceus (Bull.) Gray & Soil and woody substrate & 1 \\
\hline Subtotal & & 1 \\
\hline \multicolumn{3}{|l|}{ Russulaceae } \\
\hline Lactarius piperatus (L.) Pers. & Woody substrate & 5 \\
\hline L. plumbeus (Bull.) Gray & Woody substrate & 3 \\
\hline Subtotal & & 8 \\
\hline \multicolumn{3}{|l|}{ Schizophyllaceae } \\
\hline Schizophyllum commune Fries & Decaying wood & 3 \\
\hline Subtotal & & 3 \\
\hline \multicolumn{3}{|l|}{ Strophariaceae } \\
\hline Stropharia semiglobata (Batsch) Quel & Decaying or leafy matter & 1 \\
\hline Subtotal & & 1 \\
\hline \multicolumn{3}{|l|}{ Tricholomataceae } \\
\hline Clitocybe dealbata (Sowerby) P. Kumm. & Grassy habitats/areas & 1 \\
\hline C. gibba (Pers.) P. Kumm. & Soil and leaf litter & 6 \\
\hline Trogia infundibuliformis Berk \& Broome & Wood substrate & 36 \\
\hline Subtotal & & 43 \\
\hline Total & & 863 \\
\hline
\end{tabular}



of Quezon Protected Landscape, Southern Luzon, Philippines

Table 2 Diversity of basidiomycetous fungi collected.

\begin{tabular}{|c|c|c|c|c|c|c|c|}
\hline & Species $(i)$ & $N$ & pi & $\ln (p i)$ & piln(pi) & (-pilnpi) & $p i(\operatorname{lnpi})^{2}$ \\
\hline 1 & A. auricula & 49 & 0.0568 & -2.8686 & -0.1629 & $(0.1629)$ & 0.1580 \\
\hline 2 & A. polytricha & 29 & 0.0336 & -3.3931 & -0.1140 & $(0.1140)$ & 0.0327 \\
\hline 3 & C. dealbata & 1 & 0.0012 & -6.7604 & -0.0078 & $(0.0078)$ & 0.0000 \\
\hline 4 & C. gibba & 6 & 0.0070 & -4.9687 & -0.0345 & $(0.0345)$ & 0.0003 \\
\hline 5 & C. tenera & 7 & 0.0081 & -4.8145 & -0.0391 & $(0.0391)$ & 0.0005 \\
\hline 6 & C. micaceus & 1 & 0.0012 & -6.7604 & -0.0078 & $(0.0078)$ & 0.0000 \\
\hline 7 & C. niveus & 3 & 0.0035 & -5.6618 & -0.0197 & $(0.0197)$ & 0.0000 \\
\hline 8 & C. stercoreus & 1 & 0.0012 & -6.7604 & -0.0078 & $(0.0078)$ & 0.0000 \\
\hline 9 & Cortinarius sp. & 1 & 0.0012 & -6.7604 & -0.0078 & $(0.0078)$ & 0.0000 \\
\hline 10 & C. variabilis & 42 & 0.0487 & -3.0227 & -0.1471 & $(0.1471)$ & 0.0995 \\
\hline 11 & C. scabella & 2 & 0.0023 & -6.0673 & -0.0141 & $(0.0141)$ & 0.0000 \\
\hline 12 & Daedalia ambigua & 6 & 0.0070 & -4.9687 & -0.0345 & $(0.0345)$ & 0.0003 \\
\hline 13 & E. scabrosa & 20 & 0.0232 & -3.7647 & -0.0872 & $(0.0872)$ & 0.0107 \\
\hline 14 & E. cetratum & 8 & 0.0093 & -4.6810 & -0.0434 & $(0.0434)$ & 0.0007 \\
\hline 15 & F. pustulosa & 1 & 0.0012 & -6.7604 & -0.0078 & $(0.0078)$ & 0.0000 \\
\hline 16 & F. alveolaris & 1 & 0.0012 & -6.7604 & -0.0078 & $(0.0078)$ & 0.0000 \\
\hline 17 & G. applanatum & 3 & 0.0035 & -5.6618 & -0.0197 & $(0.0197)$ & 0.0000 \\
\hline 18 & G. lucidum & 1 & 0.0012 & -6.7604 & -0.0078 & $(0.0078)$ & 0.0000 \\
\hline 19 & H. mesophaeum & 107 & 0.1240 & -2.0876 & -0.2588 & 0.2588 & 1.6449 \\
\hline 20 & H. glaber & 7 & 0.0081 & -4.8145 & -0.0391 & $(0.0391)$ & 0.0005 \\
\hline 21 & H. nitida & 12 & 0.0139 & -4.2755 & -0.0595 & $(0.0595)$ & 0.0023 \\
\hline 22 & H. tennis & 4 & 0.0046 & -5.3741 & -0.0249 & $(0.0249)$ & 0.0001 \\
\hline 23 & H. nitida & 4 & 0.0046 & -5.3741 & -0.0249 & $(0.0249)$ & 0.0001 \\
\hline 24 & L. piperatus & 5 & 0.0058 & -5.1510 & -0.0298 & $(0.0298)$ & 0.0002 \\
\hline 25 & L. plumbeus & 3 & 0.0035 & -5.6618 & -0.0197 & $(0.0197)$ & 0.0000 \\
\hline 26 & L. velutinus & 21 & 0.0243 & -3.7159 & -0.0904 & $(0.0904)$ & 0.0124 \\
\hline 27 & L. fragillisimus & 2 & 0.0023 & -6.0673 & -0.0141 & $(0.0141)$ & 0.0000 \\
\hline 28 & M. haemetocephalus & 1 & 0.0012 & -6.7604 & -0.0078 & $(0.0078)$ & 0.0000 \\
\hline 29 & M. scorodinius & 3 & 0.0035 & -5.6618 & -0.0197 & $(0.0197)$ & 0.0000 \\
\hline 30 & Marasmius sp. & 17 & 0.0197 & -3.9272 & -0.0774 & $(0.0774)$ & 0.0066 \\
\hline 31 & M. affinis & 2 & 0.0023 & -6.0673 & -0.0141 & $(0.0141)$ & 0.0000 \\
\hline 32 & M. xanthopus & 24 & 0.0278 & -3.5824 & -0.0996 & 0.0996 & 0.0186 \\
\hline 33 & M. acicula & 8 & 0.0093 & -4.6810 & -0.0434 & $(0.0434)$ & 0.0007 \\
\hline 34 & M. alcalina & 60 & 0.0695 & -2.6661 & -0.1854 & $(0.1854)$ & 0.2900 \\
\hline 35 & M. cinerella & 20 & 0.0232 & -3.7647 & -0.0872 & $(0.0872)$ & 0.0107 \\
\hline 36 & M. clavularis & 52 & 0.0603 & -2.8092 & -0.1693 & $(0.1693)$ & 0.1888 \\
\hline 37 & M. fibula & 9 & 0.0104 & -4.5632 & -0.0476 & $(0.0476)$ & 0.0010 \\
\hline 38 & M. galericulata & 3 & 0.0035 & -5.6618 & -0.0197 & $(0.0197)$ & 0.0000 \\
\hline 39 & M. galopus & 1 & 0.0012 & -6.7604 & -0.0078 & $(0.0078)$ & 0.0000 \\
\hline 40 & M. pura & 3 & 0.0035 & -5.6618 & -0.0197 & $(0.0197)$ & 0.0000 \\
\hline 41 & M. vulgaris & 69 & 0.0800 & -2.5263 & -0.2020 & 0.2020 & 0.4411 \\
\hline 42 & Paneolus papilionaceus & 11 & 0.0127 & -4.3625 & -0.0556 & $(0.0556)$ & 0.0018 \\
\hline 43 & P. igniarius & 16 & 0.0185 & -3.9878 & -0.0739 & $(0.0739)$ & 0.0055 \\
\hline 44 & P. punctatus & 5 & 0.0058 & -5.1510 & -0.0298 & $(0.0298)$ & 0.0002 \\
\hline 45 & P. badius & 1 & 0.0012 & -6.7604 & -0.0078 & $(0.0078)$ & 0.0000 \\
\hline 46 & Polyporus sp. & 53 & 0.0614 & -2.7901 & -0.1714 & $(0.1714)$ & 0.1999 \\
\hline 47 & Polyporus sp. & 89 & 0.1031 & -2.2718 & -0.2343 & $(0.2343)$ & 0.9466 \\
\hline 48 & Poria sp. & 20 & 0.0232 & -3.7647 & -0.0872 & $(0.0872)$ & 0.0107 \\
\hline
\end{tabular}



of Quezon Protected Landscape, Southern Luzon, Philippines

(Table 2 to be continued)

\begin{tabular}{llllllll}
\hline & Species $(i)$ & $N$ & $p i$ & $\ln ($ pi) & piln(pi) & $(-p i \operatorname{lnpi})$ & pi(lnpi) \\
\hline 49 & S. commune & 3 & 0.0035 & -5.6618 & -0.0197 & $(0.0197)$ & 0.0000 \\
50 & S. semiglobata & 1 & 0.0012 & -6.7604 & -0.0078 & 0.0078 & 0.0000 \\
51 & T. ochracea & 1 & 0.0012 & -6.7604 & -0.0078 & $(0.0078)$ & 0.0000 \\
52 & T. versicolor & 8 & 0.0093 & -4.6810 & -0.0434 & $(0.0434)$ & 0.0007 \\
53 & T. infundibuliformis & 36 & 0.0417 & -3.1769 & -0.1325 & $(0.1325)$ & 0.0626 \\
\hline & Total & 863 & 1.0000 & -260.94 & -3.204170 & $(3.2042)$ & 4.14883944 \\
\hline
\end{tabular}

Table 3 Relative humidity along the transect line per quadrat.

\begin{tabular}{lll}
\hline Quadrat & Relative humidity & Number of species documented \\
\hline 1 & $78 \%$ & 14 \\
2 & $92 \%$ & 6 \\
3 & $92 \%$ & 6 \\
4 & $92 \%$ & 4 \\
5 & $100 \%$ & 3 \\
6 & $100 \%$ & 3 \\
7 & $100 \%$ & 4 \\
8 & $100 \%$ & 2 \\
9 & $100 \%$ & 9 \\
10 & $100 \%$ & 13 \\
\hline Total & & 64 \\
\hline
\end{tabular}

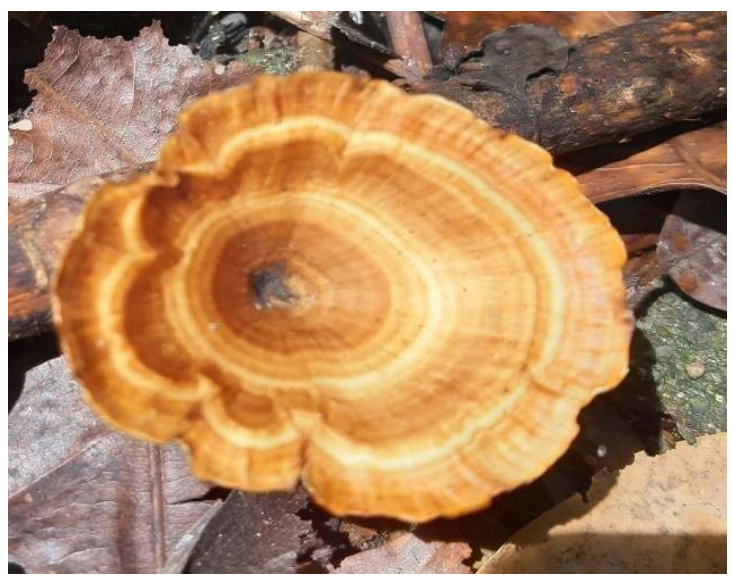

Microporus xanthopus

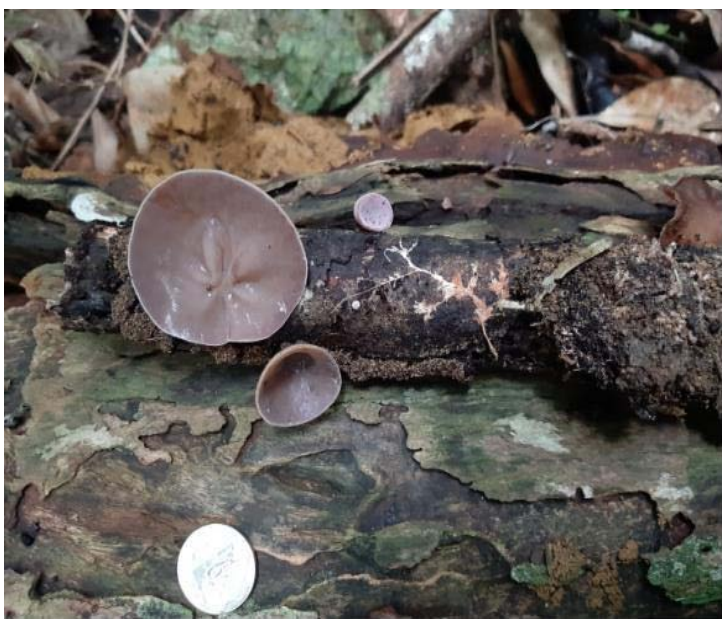

Auricularia polytricha

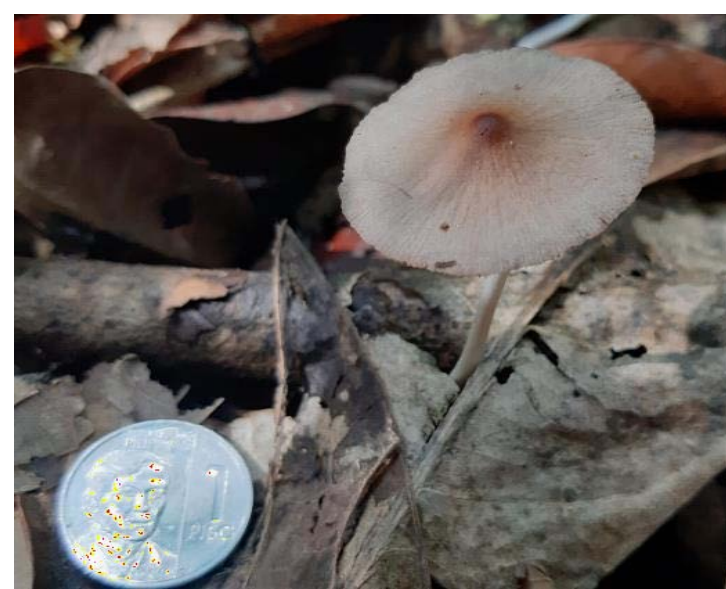

Hebeloma mesophaeum

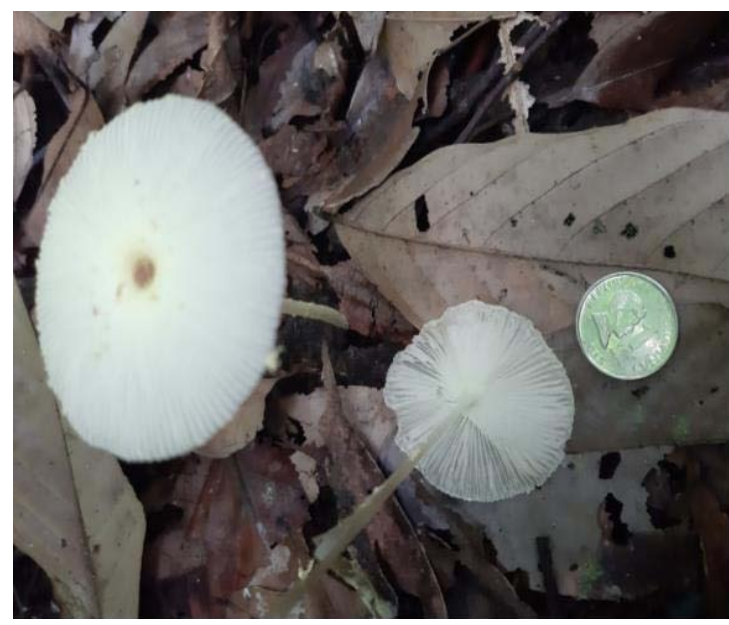

Leucocoprinus fragilissimus 

of Quezon Protected Landscape, Southern Luzon, Philippines

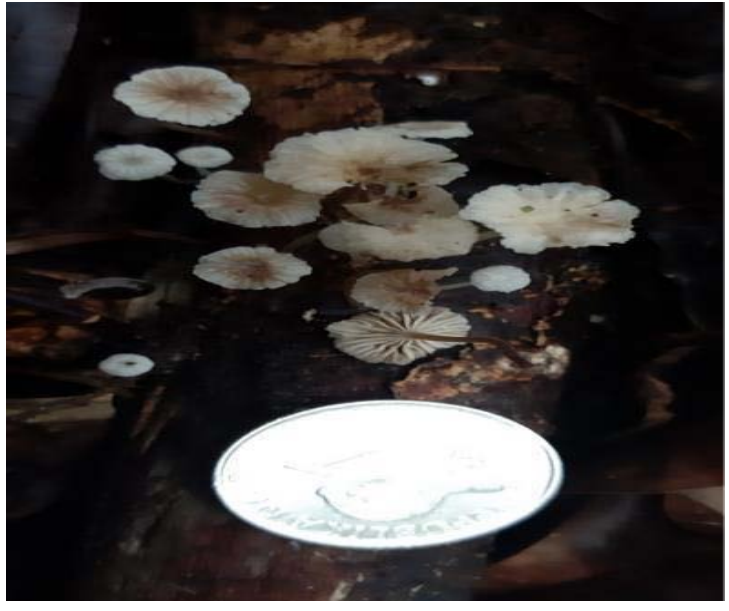

Mycena alcalina
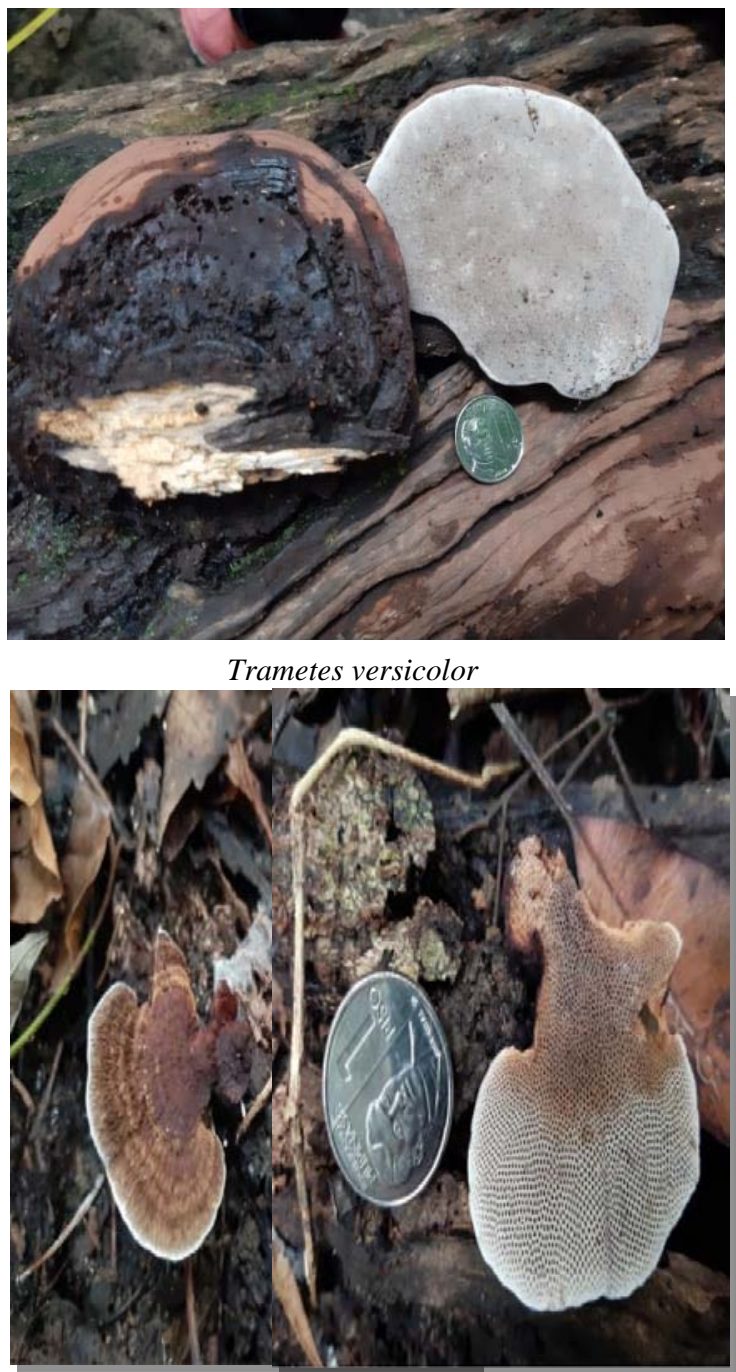

M. pura

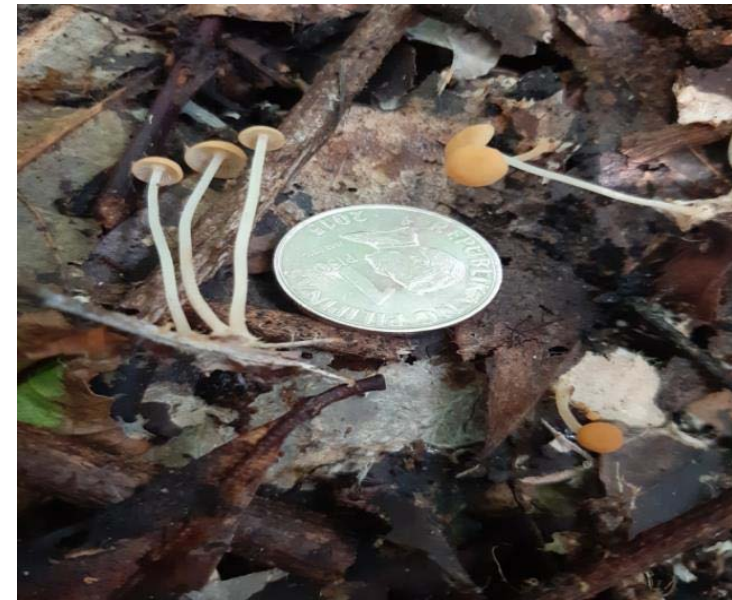

M. acicula

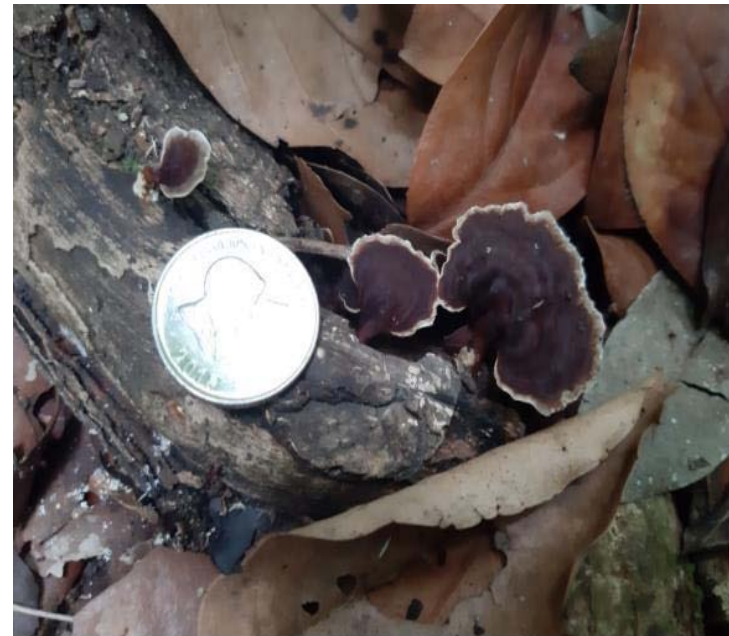

Ganoderma applanatum

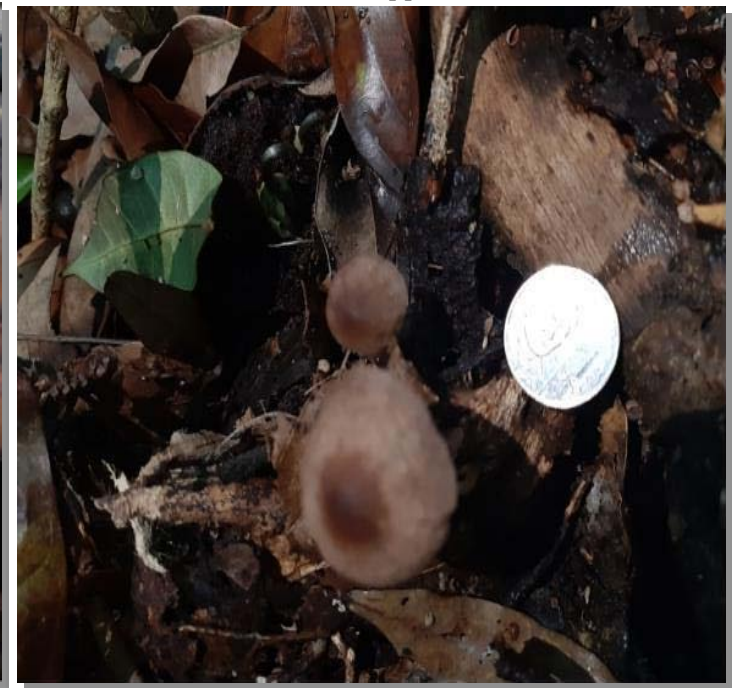

Hexagonia glaber

Fig. 2 Samples of basidiomycetous fungi collected from the northeastern side of Quezon Protected Landscape. 


\section{Conclusions}

Quezon Protected Landscape is considered as a very high priority tropical rainforest in terms of biodiversity conservation. The current study accounted 863 individual specimens of basidiomycetous fungi at the northeastern part of Quezon Protected Landscape which belong to 19 families, 31 genera and 53 species. The protected forest harbors a high diversity of these fungi due to the wide range of available habitats such as rotten wood, leaf litter, grasslands and bark of trees. Though there is high diversity of basidiomycetous fungi at Quezon Protected Landscape, there is low dominance and evenness of them in the area. With this, there is still need of continuous monitoring of the macrofungi community for sustainability and conservation of Quezon Protected Landscape as this place is open for hikers.

\section{References}

[1] Ahmadjian, V., Moore, D., and Alexopoulus, C. J. 2019. "Fungus Organisms." In Encyclopedia Britannica. https://www.britannica.com/science/fungus.

[2] Lopez-Mondejar, R., Brabcova, V., Stursova, M., and Davidova, A. 2018. "Decomposer Food Web in a Deciduous Forest Shows a High Share of Generalist Microorganisms and Importance of Microbial Biomass Recycling.” ISME Journal 12 (7): 1768-78. doi:10.1038/s41396-018-0084-2.

[3] Wang, L., and D'Odorico, P. 2013. Encyclopedia of Ecology, $2^{\text {nd }}$ ed. Amsterdam: Elsevier.

[4] Nacua, A. E., Pacis, H. J. M., Manalo, J. R., and Soriano, C. J. C. C. 2018. "Short Communication: Macrofungal Diversity in Mt. Makiling Forest Reserve, Laguna, Philippines: With Floristic Update on Roadside Samples in Makiling Botanic Gardens (MBG).” Biodiversitas 19 (4): 1579-85.

[5] Boddy, L., Money, N. P., and Watkinson, S. C. 2015. The Fungi, $3^{\text {rd }}$ ed. Cambridge, MA: Academic Press.

[6] Mueller, G. M., Schmit, J. P., Leacock, P. R., Buyck, B., Cifuentes, J., Desjardin, D. E., Halling, R. E., Hjortstam, K., Itturiaga, T., Larsson, K. H., Jean Lodge, D., May, T. W., Minter, D., Rachenberg, M., Redhead, S. A., Ryvarden, L., Trappe, J. M., Watling, R., and Wu, Q. 2006. "Global Diversity and Distribution of Macrofungi." Biodivers Conserv. 16: 37-48.
[7] Arenas, M. C., Tadiosa, E. R., Alejandro, G. J. D., and Reyes, R. G. 2015. “Macroscopic Fungal Flora of Mts. Palaypalay-Mataas na Gulod Protected Landscape, Southern Luzon, Philippines." Asian Journal of $\begin{array}{lll}\text { Biodiversity } & 6 & \text { (1): }\end{array}$ doi:http://dx.doi.org/10.7828/ajob.v6i1.693.

[8] Angeles, L. P., Arma, E. J. M., Basaca, C. W., Biscocho, H. E. H., Castro, A. E., Cruzate, S. M., Garcia, R. J. G., Maghari, L. M. E., Pagadora, R. S., and Tadiosa, E. R. 2016. "Basidiomycetous Fungi in Mts. Palay-Palay Protected Landscape.” Asian Journal of Biodiversity 7: 79-95.

[9] Briones, R. U., and Tadiosa, E. R. 2013. "Fungi of Taal Volcano Protected Landscape, Southern Luzon, Philippines.” Asian Journal of Biodiversity 4 (1): 84-98. doi:10.7828/ajob.v4i1.296.

[10] Biadnes, G. C. Q., and Tangonan, N. G. 2003. "Assessment of the Biodiversity of Basidiomycetous Fungi, Insects and Orchids in Midmontane Forest of Mt. Apo, Mindanao.” PSSN Nature News 2: 59.

[11] Daep, N. A., and Cajuday, L. A. 2003. "Mushroom Diversity at Mt. Malinao, Albay.” PSSN Nature News 2: 57.

[12] Quimio, T. 1996. “Agaricales of Mt. Makiling, Laguna, Philippines.” In Proceedings of the Asian International Mycological Congress, Chiba, Japan, 47.

[13] Quimio, T. 2001. Common Mushrooms of Mt. Makiling (Philippines). Museum of Natural History, University of the Philippines, Los Baňos, Laguna, Philippines. ISBN 97154718629789715471862.

[14] Paquit, J. C., and Pampolina, N. M. 2017. “Tree and Macrofungal Diversity of the Two Different Habitat Types in Mt. Makiling Forest Reserve.” International Journal of Microbiology and Mycology 10 (4): 1-8.

[15] Sibounnavong, P., Divina, C. C., Kalaw, S. P., Reyes, R. G., and Soytong, K. 2008. "Some Species of Macrofungi at Puncan, Carranglan, Nueva Ecija in the Philippines." Journal of Agricultural Technology 4 (2): 105-15.

[16] Tadiosa, E. R., and Soriano, A. P. 2004. "Wood Decaying Fungi at the Eastern Slope of Sierra Madre Mountain Range, Cagayan Province." In Proceedings on the Mycological Society of the Philippines (MSP) $6^{\text {th }}$ Annual Scientific Meeting and Symposium. Laguna: Ecosystem Research and Development Bureau.

[17] Tadiosa, E. R., Agbayani, E. S., and Agustin, N. T. 2011. "Preliminary Study on the Macrofungi of Bazal-Baubo Watershed, Aurora Province, Central Luzon, Philippines.” Asian Journal of Biodiversity 96: 149-71.

[18] Tadiosa, E. R. 1998. "Some Noteworthy Species of Wood-Rotting Fungi Found in the Forested Hills of La Union Province." University of Sto. Tomas Journal of Graduate Research 25 (2): 55-8. 
[19] Quimio, T. H., and Uyenco, F. R. 1985. "Keys to the Identification of Fungi: A Compilation.” Philippine Fungi. Proc. Indian Acad. Sci. (Plant Sci.) 96: 359-62.

[20] Laessoe, T. 1998. Eyewitness Handbooks: Mushrooms, the Visual Guide to More than 500 Species of Mushrooms around the World. London: Dorling Kindersley Publishers Ltd.

[21] Lincoff, G. H., and Nehring, C. 1981. National Audubon Society Field Guide to North American Mushrooms. New York: Knopf Doubleday Publishing Group.

[22] Sippola, A., Simila, M., Monkkonen, M., and Jokimaki, J. 2003. "Diversity of Polyporus Fungi (Polyporaceae) in Northern Boreal Forests: Effects of Forest Site Type and Logging Intensity." Scandinavian Journal of Forest Research 19 (2): 152-63.

[23] Rajala, T., Peltoniemi, M., Pennanen, T., and Makipaa, R. 2012. "Fungal Community Dynamics in Relation to Substrate Quality of Decaying Norway Spruce (Picea abies (L.) Karst) Logs in Boreal Forests.” FEMS Microbiology Ecology 81 (2): 494-505.

[24] Daniel, G., and Nilsson, T. 1998. "Developments in the
Study of Soft Rot and Bacterial Decay.” In Forest Products Biotechnology. London: CRC Press, 37-62.

[25] Rayner, A. D. M., and Boddy, L. 1988. Fungal Decomposition of Woods: Its Biology and Ecology. Bath: John Wiley \& Sons.

[26] Smee, D. 2010. "Species with a Large Impact on Community Structure.” Nature Education Knowledge 1 (8): 18.

[27] Stürmer, S. L., and Siqueira, J. O. 2011. "Species Richness and Spore Abundance of Arbuscular Mycorrhizal Fungi across Distinct Land Uses in Western Brazilian Amazon.” Mycorrhiza 21: 2 55-67.

[28] Grinn-Gofron, A., and Bosiacka, B. 2015. "Effects of Meteorological Factors on the Composition of Selected Fungal Spores in the Air.” Aerobiologia (Bologna) 31 (1): 63-72.

[29] Mannaa, M., and Kim, K. D. 2018. "Effect of Temperature and Relative Humidity on Growth of Aspergillus and Penicillium spp. and Biocontrol Activity of Pseudomonas protogens AS15 against Aflatoxigenic Aspergillus flavus in Stored Rice Grains.” Mycobiology 46 (3): 287-95. 